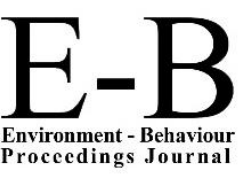

Environment - Behaviour
Proceedings Journal

\title{
AicE-Bs2015Barcelona
}

$6^{\text {th }}$ Asia-Pacific International Conference on Environment-Behaviour Studies,

Barcelona School of Architecture (ETSAB), Barcelona, Spain,31 Aug.- 05 Sep. 2015

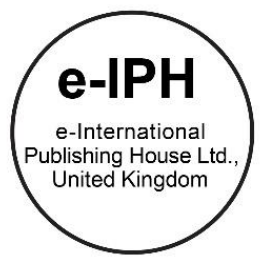

\section{Prioritization of Workplace Practices: Evidence from Islamic financial institutions}

\author{
Faizah Darus ${ }^{1 *}$, Haslinda Yusoff ${ }^{2}$ \\ ${ }^{1}$ Accounting Research Institute (ARI,) Faculty of Accountancy, Universiti Teknologi MARA Shah Alam,40450 Selangor, Malaysia \\ ${ }^{2}$ Faculty of Accountancy, Universiti Teknologi MARA Shah Alam,40450 Selangor, Malaysia
}

\begin{abstract}
The aim of this study is to examine the prioritization of workplace practices among Islamic financial institutions in Malaysia for 2012. A content analysis of the annual and sustainability reports were carried out to examine the extensiveness of disclosure relating to information on workplace practices. An Islamic workplace index was used to evaluate the workplace disclosure. The results of the study revealed that skill enhancement and employees-management engagement were the focus for workplace environment among Islamic financial institutions. Particularly, information relating to incentives and bonuses were found to be the most extensively disclosed information.

(C) 2016. The Authors. Published for AMER ABRA by e-International Publishing House, Ltd., UK. Peer-review under responsibility of AMER (Association of Malaysian Environment-Behaviour Researchers), ABRA (Association of Behavioural Researchers on Asians) and cE-Bs (Centre for Environment-Behaviour Studies, Faculty of Architecture, Planning \& Surveying, Universiti Teknologi MARA, Malaysia.
\end{abstract}

Keywords: Workplace environment; Islamic financial institutions; corporate social responsibility; Malaysia.

\section{Introduction}

An organisation recognition and obligation towards its workforce demonstrate its commitment towards the well-being of its employees and will ultimately create an organisation that is socially responsible in the workplace. There are various workplace issues that management needs to be mindful of such as employee remuneration packages, work-life balance, employee development, health and safety issues, diversity in the workplace, employee engagement platforms etc. Prior evidence suggests that research on the workplace environment in the corporate social responsibility (CSR) arena is still a relatively new and unexplored area of study. This is particularly evident among Islamic organisations.

The aim of this study is to examine the priorities in terms of the key areas that Islamic financial institutions focused on in the context of their workplace environment. An Islamic workplace index was developed to benchmark the related practices of the Islamic financial institutions. This paper is organized into four sections. The subsequent section proceeds with the literature

\footnotetext{
* Corresponding author. Tel.:+60193350388; fax:+60355444992.

E-mail address: faiza634@salam.uitm.edu.my.
} 
review of the study. The third section provides the methodology, and this is followed by the results and discussion section. The final section offers the conclusion and implications of the results.

\section{Literature Review}

\subsection{The concept of workplace from an Islamic perspective}

Being a khalifah (vicegerent) on Earth, a human being is entrusted to interact and care for other humans. Accordingly, they are expected to perform constantly the role as an executor to maintain harmony and peace for the prosperity of the Earth. Therefore, in pursuit of profit, Islam prohibits actions leading towards abuse, discrimination and exploitation, and advocates good deeds and care for people at large including employees in an organisation. For example, payment of wages should not be delayed and must be paid as soon as possible. It is haram to delay and postpone when one can pay. Prophet Muhammad SAW says:

"Your employees are your brethren upon whom Allah (SWT) has given you authority. So if one has one's brother under control, one should feed him with the like of what one eats and clothe him with the like of what one wears. You should not overburden him with what he cannot bear, and if you do so, help him in his job". (Sahih Muslim vol 2, Hadith no. 4093).

Based on the Islamic principles, derived from the Qur'an and the Sunnah, organisations are expected to care for their employees and treat them well. It includes ensuring proper workplace environment embraced by Islamic and good moral values and qualities. As Allah (swt) says:

"And We made them chiefs who guide by Our command, and We inspired in them the doing of good deeds and the right establishment of worship and the giving of alms and they were worshippers of Us (alone)." (Qur'an: Al-Anbiya, 21:73).

"And by the mercy of Allah, you dealt with them gently. And had you been severe or harsh-hearted, they would have broken away from about you; so pass over (their faults), and ask for (Allah's) forgiveness for them; and consult with them in affairs. Then when you have made a decision, put your trust in Allah." (Qur'an: Al-Imran, 3:159).

General and specific teachings in Islam cover the need to ensure proper treatment of employees under our responsibility. Among others, establish clear and proper agreements, care for the dignity of the worker, be kind to them, ensure proper and timely wages as well as acknowledge their rights to form unions and freedom of association.

\subsection{Workplace environment and employees' performance}

Quality workplace environment for employees may contribute to positive effects on their level of motivation and subsequent work productivity and general performance. Chandrasekar (2011) states that physical workplace environment in an organization is one of the primary factors for greater employees' performance. Therefore, unsafe and unhealthy workplace environment should be avoided as it could lead to negative impacts on the organization (see Ibrahim et al., 2013). Clements-Croome (2006) describes the concept of 'workplace performance' as the factor of workplace environment that is being provided by the employer to their employees. He also further highlight that it could ultimately support employees' performance at work (also Subramaniam et al., 2013; Ismail et al., 2012; Ahmad Badayai, 2012).

Some prevailing literature had discovered the link between the workplace environment and employee performance. Naharuddin and Sadegi (2013) performed a study on employees' performance in a Malaysian company known as Miyazu (Malaysia) Sdn. Bhd. and found out that workplace environment has the potential to affect the employees' performance of the company. El-Zeiny (2013) had specifically found that the interior design of workplace had a substantial influence on employees' performance. Employees who have their performance affected by bad workplace environment are often seen to react through complaints of the discomfort and dissatisfaction at the workplace (see Leaman, 1995). Such behavior signifies the existence of work-related stress; in which, stress does highly affect the occupational and behavioral performances of employees (Hashim et al., 2012).

Henceforth, this study seeks to investigate the workplace-related practices of Islamic financial institutions in a developing nation realm i.e. Malaysia. Do these financial institutions establish safe and healthy work environment for their employees? Do they conduct good deeds and responsibilities in fulfilling the basic needs and rights of the employees? Utmost, it is also interesting to understand whether their workplace-related practices are following the established Islamic laws and principles. 


\section{Methodology}

A content analysis of the annual and sustainability reports of all thirty-seven (37) Islamic financial institutions in Malaysia for the year 2012 was undertaken to investigate their workplace-related disclosure practices. Content analysis has become a leading technique for disclosure studies of published corporate reports in conveying meaning, motivations and corporate intentions. The scope that pertains to 'workplace' in this study relates to the workplace environment in an organisation where the employees are drawn from the general society. Thus, the manner in which organisation engages their staff towards being socially responsible, and whether it deals with basic human rights or gender issues. It also includes quality work environment, and that health and safety issues are obvious considerations.

The level of extensiveness of the workplace-related information disclosed in this study was ranked based on five categories, namely; non-disclosure, general information, qualitative/narrative information, quantitative information, and a combination of qualitative and quantitative information. Following the prevailing literature, accordingly scores for the level of extensiveness for workplace-related disclosures were given between 0-4 respectively (also, Sumiani, Haslinda \& Glen, 2007). An Islamic workplace index has been developed based on the review of the prevailing literature (Darus, Yusoff, A. Naim, M. Zain, Amran, Fauzi \& Purwanto, 2013).

A total number of forty-one (41) items identified under the six (6) key areas studied were regarded as essential practices that management embark on in the context of their responsibility in their workplace (see Table 1). The six (6) key areas for the workplace environment studied as the followings:

- Training and education

- Occupational safety and health administration

- Equitable opportunity

- Employment

- Awards and recognition

- Labour and management relations

These key areas are based on the concept of Maqasid al-Syariah (objectives of Syariah) and Maslahah (public good), and that are prioritised according to Islamic values of obligatory and recommended. Accordingly, Table 1 presents the detailed items based on the six (6) key areas studied. In total, the workplace-related items of disclosures were further categorised into seventeen (17) vital, and twenty-four (24) recommended items. The vital items represent essential activities to be undertaken by the Islamic financial institution while the recommended items relate to optional/suggested activities ('good to have') that could be conducted by them.

Table 1. No. of possible items according to key area for workplace environment

\begin{tabular}{ccc}
\hline Vital & Key Areas & Recommended \\
\hline 2 & 1: Training and education & 2 \\
\hline 2 & Spiritual and motivational enhancement & 1 \\
\hline 2 & Self-development & 1 \\
\hline & 2: Occupational safety and health administration & 4 \\
\hline 4 & Health and safety requirements & 2 \\
\hline 4 & 3: Equitable opportunity & 2 \\
\hline 1 & Diversity of workforce & 4 \\
\hline 2 & 4: Employment & 2 \\
\hline 1 & Remuneration and benefits \\
\hline
\end{tabular}


Darus, F., \& Yusoff, H., / 6 th AicE-Bs2015Barcelona, Spain, 30 Aug.- 04 Sep. 2015 / E-BPJ, Maiden Issue, 1(1) June 2016 (pp.401-408)

\begin{tabular}{ccc}
\hline & Incentives and bonuses & 1 \\
\hline 1 & Innovative ideas and awards & 1 \\
\hline & Loyalty packages & \\
\hline 1 & $6:$ Labour and management relations & 2 \\
\hline 17 & Employees-management engagement & 2 \\
\hline & Communication & 24 \\
\hline
\end{tabular}

\section{Findings of Study}

Table 2 presents the mean scores for the six key areas of workplace-related practices by the studied Islamic financial institutions in Malaysia. It can be seen that 'employment' is the most disclosed information (highest mean score - 12.27). This information relates to the remuneration and benefits, facilities and working conditions, employees voluntarism, and healthy working condition. This finding is followed by information related to 'training and education' for the organisations' employees, with a mean score of 10.38. These findings imply that the financial institutions have fulfilled the essential needs of their employees hence cover the basic rights of human beings; which include fair compensation, and training and development.

Table 2. Mean scores for key areas of workplace-related practice

\begin{tabular}{cccccc}
\hline & $\mathrm{N}$ & Min & Max & Mean & $\begin{array}{c}\text { Std. } \\
\text { Deviation }\end{array}$ \\
\hline $\begin{array}{c}\text { Training and education } \\
\begin{array}{c}\text { Occupational safety and health } \\
\text { administration }\end{array}\end{array}$ & 37 & 0 & 24 & 10.38 & 7.429 \\
\hline Equitable opportunity & 37 & 0 & 8 & 2.00 & 2.449 \\
\hline Employment & 37 & 0 & 42 & 12.27 & 12.002 \\
\hline Awards and recognition & 37 & 0 & 12 & 4.81 & 5.147 \\
\hline Labour and management relations & 37 & 0 & 20 & 7.16 & 5.470 \\
\hline
\end{tabular}

The key area for workplace-related disclosures with the lowest mean score is linked with 'equitable opportunity' (2.00). Such a finding indicates that the Islamic financial institutions have rather minimal practice concerning the diversity of workplace, employers-employees charter and equal opportunity among employees (based on gender, religion, race, qualification etc.).

Fig. 1. diagrammatically shows that for the vital form of workplace disclosures, the Islamic financial institutions studied had practiced and disclosed highly their skill enhancement programmes (a mean score of 4.22). This form of the programme includes essential life skills and job-related training seminars/workshops activities. Education is one of the primary good deeds in Islam and, in this case, it is the duty of the employers to facilitate education for their employees. About this matter, Prophet Mohammed (pbuh) said: "Seeking knowledge is obligatory for all Muslim men and women" (Ibn Majah).

The financial institutions also encouraged employees volunteerism programmes (mean score of 2.73); in which they encourage employees to involve actively in volunteering programmes as well as allow replacement leave for those volunteerism work. These workplace-related disclosures signify that the institutions ensure the general welfare of their employees, hence to a large extent practice good moral responsibility. As Almighty Allah commands:

"Do good to those whom your right hand possess (worker)" (Qur'an: An-Nisa', 4:37). 


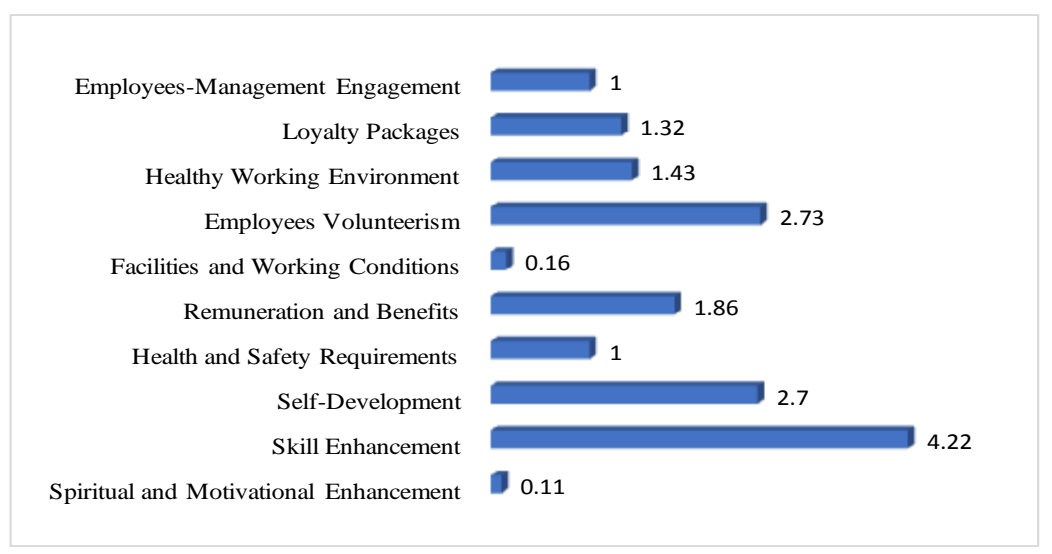

Fig. 1. Mean scores for vital workplace-related item

It has also been found that the least reported vital form of workplace disclosures relates to 'spiritual and motivational enhancement' activities - mean score of only 0.11 . The financial institutions studied had minimal tazkirah sessions with their employees. The second lowest mean score that relates to the 'facilities and working conditions' (a mean score of 0.16 ) indicates that the institutions make minimal available facilities of prayer rooms for their employees. These findings contradict with the teachings of Islam which require organisations to enrich the spiritual needs of their employees (faith, good behaviour, social concern and pursuit of truth, patience in adversity):

'So remember Me; I will remember you. And be grateful to Me and do not deny Me”. (Qur'an: Al-Baqarah, 2:152).

Fig. 2. illustrates the mean scores for recommended form of workplace-related disclosures made by the Islamic financial institutions. It has been discovered that the highest level of the extent of disclosures relates to information about 'employeesmanagement engagement' (a mean score of 4.08). The financial institutions had conducted various festival events and corporate activities involving all level of employees. The activities include Islamic related celebrations (e.g. Awal Muharram, Maulidur Rasul) and other events such as Annual Dinner, Family Day and Sports Competition.

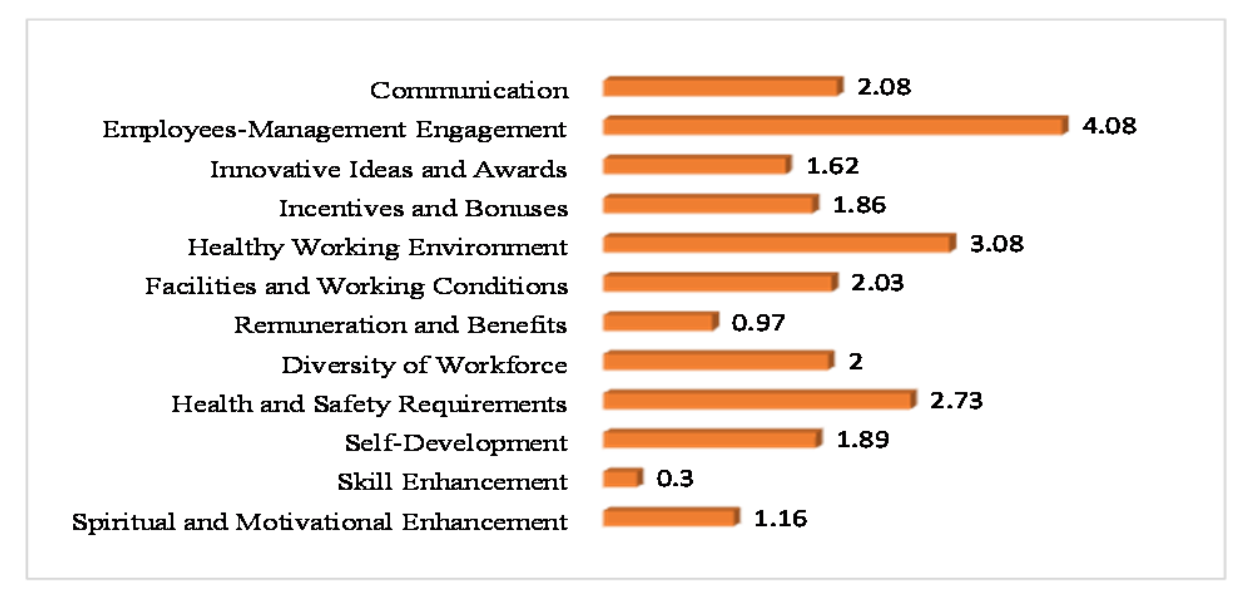

Fig. 2. Mean scores for recommended workplace-related items

The disclosure with the second highest mean score relates to 'healthy working environment' (a score of 3.08). Such a finding indicates that the financial institutions involved have high accountability in ensuring that their employees' working environment is conducive. This practice is consistent with the concern about safety precautions in other industry sectors (e.g. Ismail \& Ghani, 2012). Specifically, 'healthy working environment' relates to the efforts of the financial institutions to conduct health and safety awareness programmes and to provide supplementary equipment/devices/materials for the healthy working environment. These 
findings denote that management of the financial institution practice good management, which is based on the concept of Shura (meetings) and Muawanah (cooperation). Such an approach gets employees' involvement in their activities toward ensuring safety, health and welfare of employees at the workplace. Fig. 2. also shows that the least disclosed recommended form of workplace-related information by the Islamic financial institutions is 'skill enhancement', with a mean score of 0.3. Particularly, the institutions offered minimal Syariah references/information to their employees. This is rather disappointing being an Islamicbased organisation, the financial institutions could have played the essential role in promoting and disseminating Islamic and 'good' value-based knowledge for the benefit of their workers. The second recommended item with lowest means score relates to 'remuneration and benefits' - score of 0.97 . It has been learnt that minimal disclosures were reported on the fringe benefits to employees including takaful protection, payment holiday benefits, travelling allowances, and housing allowances. Besides that, insignificant amount of information that pertain to subsidising umrah/haj expenses for employees and their family members had been disclosed in the corporate reports.

Table 3 provides the level of extensiveness based on average means and rankings of workplace-related disclosures made by all 37 Islamic financial institutions studied. The disclosures were minimal, with the average mean ranging between 0.32 and 1.86 (at a maximum score of 4.00). These 13 items of disclosures categorised, under the six key areas of workplace environment, have been made primarily in the form of general statements i.e. one sentence of information concerning the workplace-related programmes and activities carried out by the respective financial institutions. On the whole, the most reported information relates to 'incentives and bonuses' followed by employees-management engagement. While, the least reported workplace-related information is 'spiritual and motivational enhancement', followed by facilities and working conditions.

Table 3. Level of extensiveness and ranking for workplace-related practice items

\begin{tabular}{|c|c|c|}
\hline \multirow{2}{*}{ Key Area } & \multicolumn{2}{|c|}{ Level of extensiveness } \\
\hline & Average Mean & Ranking \\
\hline \multicolumn{3}{|c|}{ Training and Education } \\
\hline Spiritual and Motivational Enhancement & 0.32 & 13 \\
\hline Skill enhancement & 1.51 & 5 \\
\hline Self-development & 1.53 & 4 \\
\hline \multicolumn{3}{|c|}{ Occupational Safety and Health Administration } \\
\hline Health and Safety Requirements & 0.75 & 10 \\
\hline \multicolumn{3}{|c|}{ Equitable opportunities } \\
\hline Diversity of Workforce & 1.00 & 9 \\
\hline \multicolumn{3}{|c|}{ Employment } \\
\hline Remuneration and Benefits & 0.47 & 11 \\
\hline Facilities and Working Conditions & 0.44 & 12 \\
\hline Employees volunteerism & 1.37 & 6 \\
\hline Healthy working environment & 1.51 & 5 \\
\hline \multicolumn{3}{|c|}{ Awards and Recognition } \\
\hline Incentives and Bonuses & 1.86 & 1 \\
\hline Innovative Ideas and Awards & 1.62 & 3 \\
\hline Loyalty packages & 1.32 & 7 \\
\hline \multicolumn{3}{|c|}{ Labour and Management Relations } \\
\hline Employees-management engagement & 1.69 & 2 \\
\hline Communication & 1.04 & 8 \\
\hline
\end{tabular}




\section{Summary and Conclusions}

The results of this study expand our understanding about the workplace initiatives from the case study of Islamic financial institutions' disclosure practices in Malaysia. To a certain extent, it can be concluded that from the Islamic perspective, the Islamic financial institutions are dedicated to the discharging of their responsibilities towards providing satisfactory workplace environment to their employees.

In the prioritization of workplace-related activities into vital and recommended forms, the content analysis carried out on information made available in corporate annual and sustainability reports has resulted with the financial institutions reporting various activities and incentives. Concerning vital activities, the results of this study revealed that the financial institutions had focused on enhancing employees' skills through education. Whereas for the recommended activities, high disclosures have been made that pertain to the active employee-management engagement activities.

These findings put forward some ideas that the management of these organisations conducts good deeds towards the protection of safety, health and welfare of their employees. Thus, portrays the degree of their duties as the khalifah of God on Earth. One fulfills his responsibility towards the employees by undertaking activities in line with the protection of the objective of Syariah (Maqasid al-Shariah) and ultimately promotes public good (Maslahah). Nevertheless, the slight downfall from this study is in terms of the minimal extent of the overall workplace-related disclosures; which is primarily in the general form of reporting to the public at large. Thus, the Islamic financial institutions should engage with greater disclosure practice towards fulfilling the information demands from various stakeholder groups.

In conclusion, Islamic financial institutions should intensify their efforts towards better workplace environment for their employees, and that most importantly the efforts must be made in accordance with Islam. Islam believes in freedom, justice and equality, and tolerance in the workplace. The financial institutions should ensure the vital form of workplace activities be carried out to the maximum, while not forgetting that the recommended activities are also greatly encouraged. There is a clear connection between environment and human behaviour; thus, good workplace environment and high concerns from the organisation will induce greater respect and loyalty amongst employees. Subsequently, employees can work thankfully and continuously increase the productivity of the organisations. Future research may extend the years of studies and explore the trend of CSR-related practices by the sampled institutions. Also, further investigation may be conducted by analyzing the core influencing factors of the institutions against the workplace-related disclosure practice.

\section{Acknowledgements}

The authors would like to express their gratitude to the Ministry of Education, Malaysia for funding this research under the FRGS grant and the Accounting Research Institute (ARI), Universiti Teknologi MARA for facilitating this research project.

\section{References}

Ahmad Badayai, A. R. (2010). A theoretical framework and analytical discussion on uncongenial physical workplace environment and job performance among workers in industrial sectors. Procedia - Social and Behavioral Sciences, AcE-Bs 2010, 42, 486-495.

Chandrasekar, K. (2011). Workplace environment and its impact on organisational performance in public sector organizations. International Journal of Enterprise Computing and Business System. 1(1), 1-20.

Clements-Croome, D. (2006). Creating the productive workplace, (2nd ed). Oxford, England, Taylor and Francis.

Darus, F., Yusoff, H., Abang Naim, D.M., Mohamed Zain, M., Amran, A., Fauzi, H., \& Purwanto, Y. (2013). Islamic corporate social responsibilities (i-CSR) framework for Islamic banks: application of maqasid al-syariah and maslahah principles. Issues in Social and Environmental Accounting (ISEA). 7(2), 102112.

El-Zeiny, R. M. A. (2013). Interior design of workplace and performance relationship: private sector corporations in Egypt. Asian Journal of EnvironmentBehaviour Studies, 4(14), 49-62.

Hashim, A. E., Isnin, Z., Ismail, F. Norrihan, N. A., \& Razali, R. (2012). Occupational stress and behavioural studies of facilities management employees in commercial complex. Journal of ASIAN Behavioural Studies. 2(6), 63-72. 
Ibrahim, I. I., M. Noor, S., Nasirun, S., \& Ahmad, Z. (2013). Favourable working environment in promoting safety at workplace. Journal of ASIAN Behavioural Studies. 3(13), imprint.

Ismail, F., Hashim, A.E., Wan Ismail, W.Z., Kamarudin, H., \& Ahmad Baharom, Z. (2012). Environment improvement: Malaysian experience in the oil and gas industry. Procedia - Social and Behavioral Sciences, AicE-Bs 2011, 35, 586-594.

Ismail, H. I., \& Ab Ghani, K. D. (2012). Potential hazards at the construction workplace due to temporary structures. Procedia - Social and Behavioral Sciences, 1nCEBS2009, 49, 168 - 174.

Leaman, A. (1995). Dissatisfaction and office productivity. Facilities. 13(2), 13-19.

Naharuddin, N. M., \& Sadegi, M. (2013). Factors of workplace environment that affect employees' performance: A case study of Miyazu Malaysia. International Journal of Independent Research and Studies. 2(2), 66-78.

Salem, Z. O., \& S. Agil, S.O. (2012). The effects of Islamic management ethics on organizational commitment of employees in Libyan public banks. Australian Journal of Basic and Applied Sciences. 6(7), 260-270.

Subramaniam, G., Tan, P., Maniam, B., \& Ali, E. (2013). Workplace flexibility, empowerment and quality of life. Procedia - Social and Behavioral Sciences, AicEBs2013, 105, 885-893.

Sumiani, Y., Haslinda, Y., and Lehman, G. (2007). Environmental reporting in a developing country: a case study on status and implementation in Malaysia. Journal of Cleaner Production. 15(10), 895-901. 